\title{
Student's Food Buying Interest Using an Online Delivery Order Application
}

\author{
Widodo ${ }^{*}$ and Shifa Anissa Amalia \\ Department of Agribusiness, Universitas Muhammadiyah Yogyakarta, Indonesia
}

\begin{abstract}
Food online delivery service had been present in various cities in Indonesia such as Yogyakarta. Delivery service provides a new experience for consumers in buying food. This research aimed to describe student's food buying interest using online delivery order application. The research applied the Theory of Planned Behaviour by Ajzen and Fishbein. This research was conducted at the Universitas Muhammadiyah Yogyakarta. The sampling technique in this study used accidental sampling collected 200 students. The average score of the data was taken to describe the category of the student's level of interest. The results showed that the students favorable to order food using the online delivery order application, the environment around the students did not support on using of the online delivery order application, and the transaction facilities supported the use of the online delivery order application. Overall, the results showed that students did not show a strong interest in buying food through online delivery order application.
\end{abstract}

\section{Introduction}

E-commerce market in Indonesia grows rapidly for last years. E-commerce users increase every year, data shows e-commerce users in Indonesia in 2017 reached 139 million and increased in 2018 by $10.8 \%$ to 154.1 million users. E-commerce users in Indonesia are predicted continue to increase in subsequent years [1]. Census data of the Central Statistics Agency (BPS) shows that the Indonesian e-commerce industry in the last ten years has increased 17 percent. Food, beverages, and groceries; fashion; and cosmetics, were the three largest groups of goods sold through e-commerce transactions [2].

Indonesia's online market has grown tremendously. The Merchant Machine research institute released that Indonesia is the country with the fastest online trade growth in the world, which was $78 \%$ in 2018 . The average money spent by Indonesian people on online shopping sites reached US\$ 228 per person or around IDR 3.19 million per person in 2018 [3]. Online delivery providers played an unprecedented role. A finding of a study provide guidelines for online delivery providers in engaging consumers with online food delivery services [4].

Information technology is progressing very rapidly and has an influence on various aspects on humans' life. The most obvious impact of information technology development,

\footnotetext{
*Corresponding author: widodo@umy.ac.id
} 
especially on smartphone were changes in the way humans transact. One of the smartphone applications was food orders that makes easy for people to meet their daily needs in purchasing food. The food ordering service application provided by digital companies has received a tremendous response from the Indonesian people. The Gojek application in 2019 has been downloaded by 142 million downloads and the Grab application has been downloaded by 144 million downloads [5]. This delivery application provides a new experience for the community in making food purchases. The environmental conditions that determine people's interest in conventional food purchases have been shifted with various conveniences provided in food ordering service applications. Based on this problem, the research problem that arises is whether the condition of convenience in the application of food delivery services is a determinant of consumer interest in buying food.

In pandemic Covid-19, consumers decreased their purchasing mobility for food and switched it into online shopping although consumers induced to pay more to cover the cost of delivery services for the food products. This shift of purchasing habit will continue for next years, especially by millennial generation, included the change on trips for food purchasing, Due to the differences on consumers' preferences for online shopping and on traditional offline markets, the marketing emphasis of one industry needs to be adjusted to this habit change [6].

The theory of planned behaviour was widely applied for some investigations on agribusiness. This theory was used for investigating the relationship between consumers attitude and their purchasing action for some food and other agriculture product. A study in Iran students investigated the students' intentions on purchasing for organic food. This research showed that both perceived behaviour control and subjective norms were not significant predictors of students' intentions [7]. Other study in Belgium, showed that favourable buying attitude, high subjective norms and high perceived behaviour control positively impacted on consumers decisions for fish consumption, and some individual determinants pertained to gender, age, children, income, education level and region [8]. Moreover, purchasing intentions was significantly predicted by purchasing attitude and perceived behaviour control. Consumers beliefs on positive effects on health and environment has a significant effect on attitudes and intentions on eating an insect-based food product [9].

\section{Method}

This research was conducted at the University of Muhammadiyah Yogyakarta, which has 19,791 students from a total of 247,882 students in D.I. Yogyakarta. Moreover, in Yogyakarta, there are 846 restaurants and 1,163 restaurants, as well as many restaurants or restaurants that work with food delivery service application companies. Samples were taken from students who coincidentally met with researchers at the University of Muhammadiyah Yogyakarta campus. The selected respondents are students who have downloaded, opened, and bought food or drinks using an application of food order. A number of students who were willing to become respondents were 200 people for one week survey.

Data were collected by distributing questionnaires to respondents to fill out themselves. The questionnaire is divided into 3 parts, namely, consumer attitudes in purchasing food through application of food order, consumer subjective norms in purchasing food through application of food order, and behavioral control that determines food purchases through application of food order. Each statement in the questionnaire was given a response from strongly disagree which was given a score of 1 to strongly agree which was given a score of 5 .

The data were analyzed based on the theory of planned action [10].

$$
B I=\omega_{1}\left(A_{a c t}\right)+\omega_{2}(S N)+\omega_{3}(P B C)
$$




$\begin{array}{ll}\mathrm{BI} & =\text { Intentions to purchase food } \\ \mathrm{A}_{\mathrm{act}} & =\text { attitude toward purchasing food } \\ \mathrm{SN} & =\text { subjective norms } \\ P B C & =\text { perceived behaviour control }\end{array}$

\section{Results and Discussion}

The introduction of online food ordering by some digital company has create new habit of young Indonesian consumers. Although consumers paid more delivery service dan digital company service, consumers switched to online purchasing for food. To attract a wide market target, some digital online food order offered some conveniences. Table 1 showed some services that motivated customers to purchasing food through application of food order.

Table 1. Respondents' motive on purchasing food through application of food order

\begin{tabular}{|c|c|c|}
\hline Purchasing motive & Number of respondents & Percentage (\%) \\
\hline Save the time & 85 & 42.5 \\
\hline Ease to perform & 141 & 70.5 \\
\hline Take advantage of promotion & 126 & 63 \\
\hline Save the money & 14 & 7 \\
\hline Due to rainy weather & 5 & 2.5 \\
\hline
\end{tabular}

Most of respondents are motivated by ease to perform the purchasing through this application, take advantage of any promotion. The food order application is an application that can be installed on smartphones based on Android and Apple. Applications installed on both smartphone operating systems provide the same convenience for users to operate the smartphone. Research respondents who are students are millennials who are very familiar with smartphones. So that most of them make food purchases with a push that is easy to do and saves time.

Most respondents spend pocket money of a maximum of IDR 2,000,000 a month for the purposes of daily life, such as eating and drinking, paying telephone bills, bathing needs, transportation, and others. With the limited amount of pocket money, respondents will buy food in a frugal way. Thus, respondents often take advantage of promotional programs organized by application companies. Table 1 shows that $63 \%$ of students take advantage of promotional programs to get cheap prices for food and beverages ordered through the food order application. The research on generation $\mathrm{Y}$ found that trust and price consciousness exhibit positive effects on purchase intention [11].

Table 2. Respondents' attitude toward purchasing food through application of food order

\begin{tabular}{|c|c|c|c|c|}
\hline $\begin{array}{c}\text { Purchasing } \\
\text { attribute }\end{array}$ & $\begin{array}{c}\text { Score of believe } \\
\text { strength }\end{array}$ & $\begin{array}{c}\text { Score of believe } \\
\text { evaluation }\end{array}$ & $\begin{array}{c}\text { Score of } \\
\text { attitudes }\end{array}$ & $\begin{array}{c}\text { Category of } \\
\text { attitude }\end{array}$ \\
\hline Food price & 3.10 & 4.30 & 13.33 & Neutral \\
\hline Food variation & 3.84 & 4.16 & 15.97 & Favourable \\
\hline Food freshness & 3.68 & 4.47 & 16.45 & Favourable \\
\hline Deliver quickly & 3.61 & 4.33 & 15.63 & Favourable \\
\hline Serve preciously & 3.85 & 4.53 & 17.44 & Favourable \\
\hline Promotion & 3.79 & 4.35 & 16.49 & Favourable \\
\hline Delivery cost & 3.31 & 4.43 & 14.66 & Neutral \\
\hline $\begin{array}{c}\text { Attitude toward } \\
\text { purchasing }\end{array}$ & 3.60 & 4.37 & 15.71 & Favourable \\
\hline
\end{tabular}


Individuals' intention to perform behaviour was the antecedent of that behaviour. Based on the theory of reason action, for some agribusiness marketing cases, attitude toward purchasing food and the subjective norms influenced the consumers' intention for food purchasing [12]. On this theory, individuals are considered inseparable from their social life [13].

Attitude is an individual perceive about a performing of purchasing food through application of food order, both favorable and unfavorable feeling. An individual will intend to perform a purchasing food through application of food order when he or she take benefit from it. Attitudes are defined by belief of individual about the advantage of his/her performing of the purchasing, weighted by his/her evaluation of these purchasing advantage [14]. My research showed that some attributes are favorable to perform this behaviour. Some purchasing food through application of food order consumers may provide some variation of food, serve food freshly, food stall owner served precisely, and Application Company give some promotion program, such as price discount, purchasing voucher, discount on delivery cost. Variable trust and online shopping experience affected toward dependent variable of attitude [15].

A subjective norm is determined by individual normative belief and motivation to carry out the normative belief. A normative belief is expectation of others regarding the important of behavior. For some purchasing behaviour, normative belief is defined by the influence of family member and colleague who leads consumers to conform be liked and accepted by them. Motivation to comply is perceived pressure from others to an individual for match his or her behavior to the perceived expectation of others [16].

Table 3. Respondents' subjective norms on purchasing food through application of food order

\begin{tabular}{|c|c|c|c|c|}
\hline $\begin{array}{c}\text { Source of } \\
\text { norms }\end{array}$ & $\begin{array}{c}\text { Score of } \\
\text { normative } \\
\text { believe }\end{array}$ & $\begin{array}{c}\text { Score of } \\
\text { motivation to } \\
\text { comply }\end{array}$ & $\begin{array}{c}\text { Score of } \\
\text { subjective } \\
\text { norms }\end{array}$ & $\begin{array}{c}\text { Category of } \\
\text { subjective norms }\end{array}$ \\
\hline $\begin{array}{c}\text { Family } \\
\text { members }\end{array}$ & 2.98 & 3.27 & 9.74 & Disapprove \\
\hline Colleague & 3.30 & 3.43 & 11.32 & $\begin{array}{c}\text { Moderately } \\
\text { approve }\end{array}$ \\
\hline $\begin{array}{c}\text { Subjective } \\
\text { norms }\end{array}$ & 3.14 & 3.35 & 10.53 & Disapprove \\
\hline
\end{tabular}

Subjective norms are individual beliefs for agree or disagree of the behavior. Although an individual was disagreed for a food purchasing, subjective norms might pressure on an individual to accept the social norms. Normative norms shown provide a high persuasive effect on individuals. An individual intended to purchase food through application food order when he/she perceives that important people, such as family members or colleagues think he/she should do so. Most important people were like or dislike of their purchasing food through application food order [14]. My research showed that the respondents are disapprove to person around them support this behavior. A Study on fast food restaurants revealed that specific referent groups lead fast-food consumption as well as a general demand for meals that are tasty, satisfying, and convenient [17]. However, a research that be conducted in Jambi showed that subjective norm did not effect to intention on using GoFood application [18].

Theory of planned behaviour's central premise is that a precise behaviour is a function of the intention to perform this behaviour and the perceived behavioural control. The stronger intention and perceived behavioural control are the more likely the behavioural 
performance will be. The intention is determined by the combination of attitudes, subjective norms, and perceived behavioural control [19].

The construct of perceived behavioural control was added in an attempt to deal with situations in which people may lack complete volitional control over the behaviour of interest [16].

More favourable attitude and subjective norms and greater perceived behavioural control correspond to a greater likelihood of consumer intention to purchase food through application of food order. Perceived behaviour control is considered as a function of control beliefs and perceived power. Control beliefs is ones related to presence or absence of the resource and opportunities required to perform the behaviour. Perceived power is the ability of the control attribute to facilitate or inhibit the performance of behaviour.

Table 4. Respondents' perceived behaviour control on purchasing food through application of food order

\begin{tabular}{|l|c|c|c|c|}
\hline \multicolumn{1}{|c|}{$\begin{array}{c}\text { Source of } \\
\text { behaviour } \\
\text { control }\end{array}$} & $\begin{array}{c}\text { Score of } \\
\text { believe } \\
\text { control }\end{array}$ & $\begin{array}{c}\text { Score of } \\
\text { perceived } \\
\text { power }\end{array}$ & $\begin{array}{c}\text { Score of perceived } \\
\text { behaviour control }\end{array}$ & $\begin{array}{c}\text { Category of } \\
\text { behaviour } \\
\text { control }\end{array}$ \\
\hline $\begin{array}{l}\text { Ease to use the } \\
\text { application }\end{array}$ & 4.35 & 4.17 & 18.14 & Support \\
\hline $\begin{array}{l}\text { Ease to pay the } \\
\text { food purchasing }\end{array}$ & 4.33 & 4.12 & 17.84 & Support \\
\hline $\begin{array}{l}\text { Ease to recharge } \\
\text { e-money }\end{array}$ & 4.05 & 3.92 & 15.88 & Support \\
\hline $\begin{array}{l}\text { Perceived } \\
\text { behaviour } \\
\text { control }\end{array}$ & 4.24 & 4.07 & 17.29 & Support \\
\hline
\end{tabular}

Perceived behaviour control is factor that restrain the individual's decision to perform the purchasing food through application of food order. The perceived behaviour control could push purchasing food through application of food order if a person gets benefits by using the application, and that he/she is able to reuse the application in the future after evaluating it. Although a study found that perceived behaviour control did not effect on intention [15], however my research showed that application feature supported respondent to purchasing food through application of food order. This is because perceived behavioural control could directly affect the intention by increasing the effort to goal achievement [20], but my research findings show that the perceived behavioural control facilitate the consumer to perform purchasing more easily.

The aggregation such dimension of the theory of planned behaviour was intended to demonstrate that general attitudes which affected to human behaviour, but the effect was valid on the behavior of the sample. Specific behaviour in specific situations is greatly weakened by some immediate factors. Indeed, it may be argued that attitudes toward purchasing have an impact on specific behaviour on purchasing intentions on food through application of food order but it was indirectly influenced by some factors [12].

Table 5. Respondents' purchasing intentions on food through application of food order

\begin{tabular}{|c|c|c|}
\hline Component of intentions determinant & Weight (\%) & Score \\
\hline Attitude to purchasing & 0.35 & 15.71 \\
\hline Subjective norms & 0.30 & 10.53 \\
\hline Behaviour control & 0.35 & 17.29 \\
\hline Purchasing intentions & & 14,71 (Moderate) \\
\hline
\end{tabular}


In the theory of planned behaviour, Ajzen attempted to extend the theory of reason action by evolving the perceived behavioural control. This theory proposed a framework in which via intentions, behaviour was determined by attitude toward behaviour, subjective norms, and perceived behavioural control. Perceived behavioural control is factors which control the individual's decision to perform the behaviour. Perceived behavioral control is representative for real control which is considered to moderate the effect of intention on behaviour [16].

My research showed that respondent intentions to purchasing food through application of food order are in moderate category. It means that respondent will purchase if they meet favourable attitude to purchase stimulation, such as promotion season, new menus, or rainy situation. The subjective norm did not determine the intentions to purchasing food through application of food order due to this food purchasing was performed privately by his/her smartphone. Due to the respondent of this research were millennial and Y generation, they were familiar with some new application which installed on their smartphone, and they perceived all ease. They were more motivated to utilize the applications to online purchasing because they want to get greater benefits. The findings of this study update previous research that consumers with less experience in e-commerce need more attractive elements to encourage them to adopt it, meanwhile the experienced consumers need some hedonic items [21]. My research support to other finding that the most important reason for the rise of e-commerce is a more reasonable price [22]. Other finding revealed that consumers will purchase using online channels if it will be profitable, efficient, effective and productive [23].

\section{Conclusion}

This research applied the theory of planned behaviour to describe student's food purchasing interest using online delivery order application. This research was conducted at the Universitas Muhammadiyah Yogyakarta and collected 200 respondents of student. This research showed that most of respondents of student were motivated by ease to perform the purchasing through this application, take advantage of any promotion. Respondents of student perceived easy to operate all application of food order which provided by such digital company, feel easier to pay the billing and to recharge their e-money. This finding updated the previous research that consumers with less experience in e-commerce need more functional elements to adopt it. Purchasing food through application food order was a private activity, they did not consider to their normative social regarding to their behaviour. The respondents of student were interested to the facilities due to applying online delivery order, such as price discount, more menu choices, precise serving.

\section{Reference}

1. J. Muller, Statista (2020).

2. L. Anggraini, S. Utoyo, and E. Sari, editors, Statistik E-Commerce 2020 (BPS-Statistics Indonesia, Jakarta, 2020).

3. Merchantmachine.co.uk, Merch. Mach. (2019).

4. R. Cai and X. Y. Leung, Int. J. Hosp. Manag. 91, 102677 (2020).

5. Katadata, Katadata.Co.Id (2019).

6. W. Yue, N. Liu, Q. Zheng, and H. H. Wang, Foods 10, 2156 (2021).

7. M. Yazdanpanah and M. Forouzani, J. Clean. Prod. 107, 342 (2015).

8. W. Verbeke and I. Vackier, Appetite 44, 67 (2005). 
9. D. Menozzi, G. Sogari, M. Veneziani, E. Simoni, and C. Mora, Food Qual. Prefer. 59, 27 (2017).

10. U. Sumarwan, Perilaku Konsumen: Teori Dan Penerapannya Dalam Pemasaran., 2ed ed. (PT Ghalia Indonesia, Jakarta, 2016).

11. G.-W. Zheng, N. Akter, A. B. Siddik, and M. Masukujjaman, Foods 10, 2278 (2021).

12. I. Ajzen, Organ. Behav. Hum. Decis. Process. 50, 179 (1991).

13. R. Davis, R. Campbell, Z. Hildon, L. Hobbs, and S. Michie, Health Psychol. Rev. 9, 323 (2015).

14. T. T. H. Nguyen, N. Nguyen, T. B. L. Nguyen, T. T. H. Phan, L. P. Bui, and H. C. Moon, Foods 8, 1 (2019).

15. S. Assegaff, J. Apl. Manaj. 13, 463 (2015).

16. I. Ajzen, J. Appl. Soc. Psychol. 32, 665 (2002).

17. K. I. Dunn, P. Mohr, C. J. Wilson, and G. A. Wittert, Appetite 57, 349 (2011).

18. H. Hendri, M. Saudina, and E. Effiyaldi, J. Ilm. Media Sisfo 14, 1 (2020).

19. E. Giampietri, F. Verneau, T. Del Giudice, V. Carfora, and A. Finco, Food Qual. Prefer. 64, 160 (2018).

20. M. Nursalwani and A. L. Zulariff, Can. Soc. Sci. 13, 43 (2017).

21. N. Peña-García, I. Gil-Saura, A. Rodríguez-Orejuela, and J. R. Siqueira-Junior, Heliyon 6, (2020).

22. Y. Wei, C. Wang, S. Zhu, H. Xue, and F. Chen, Front. Psychol. 9, 1 (2018).

23. C. K. Dewi, Z. Mohaidin, and M. A. Murshid, J. Asia Bus. Stud. 14, 281 (2019). 